\title{
ЗМІНИ БІОХІМІЧНИХ ПОКАЗНИКІВ І ФУНКЦІОНАЛЬНОЇ АКТИВНОСТІ СЕРЦЯ ВИСОКО- І НИЗЬКОСТІЙКИХ ДО ГОСТРОЇ ГІПОКСИЧНОЇ ГІПОКСІЇ ЩУРІВ РІЗНОЇ СТАТІ ПРИ ІММОБІЛІЗАЦІЙНОМУ СТРЕСІ
}

Вступ. Визначення механізмів ушкоджувального впливу стресу на серце в осіб з різною реактивністю може сприяти розробці індивідуальних методів корекції.

Мета дослідження - визначити вплив іммобілізаційного стресу на зміни пероксидного окиснення ліпідів, антиоксидантного захисту та показники електрокардіограм у щурів різної статі з високою і низькою стійкістю до гіпоксії (ВГ та НГ).

Методи дослідження. Стрес моделювали 4 рази шляхом одногодинної іммобілізації щурів спинкою донизу з інтервалом 24 год. У серці визначали концентрацію дієнових і трієнових кон'югатів, шифрфових основ, ТБК-активних продуктів, активність супероксиддисмутази, каталази. Реєстрували електрокардіограми.

Результати й обговорення. У контрольних ВГ самців, порівняно з НГ, виявлено нижчу активність процесів пероксидного окиснення ліпідів, вищу активність супероксиддисмутази, у ВГ самиць порівняно $з$ НГ - більше продуктів пероксидного окиснення ліпідів, супероксиддисмутази, меншу активність каталази. Іммобілізація призвела до розвитку окиснювального і карбонільного стресу, більше в самців порівняно із самицями. При дослідженні електрокардіограм тільки за умов стресу у ВГ самиць збільшились амплітуда зубця R, відхилення ST відносно ізолінії, у НГ зросла частота серцевих скорочень, зменшилася тривалість інтервалів RR і QTC.

Висновки. Інтервальна іммобілізація щурів призводить до окиснювального та карбонільного стресу в серці, але механізми його розвитку залежать від стійкості до гіпоксії і статі. При іммобілізаційному стресі зміни на електрокардіограмах відмічено тільки в самиць.

КЛЮЧОВІ СЛОВА: стрес; щури; резистентність до гіпоксії; пероксидне окиснення ліпідів; антиоксидантна система; електрокардіограми.

ВСТУП. Індивідуальна реакція на стрес може залежати від віку, статі, особливостей автономної регуляції, стану центральної нервової, ендокринної систем, вищої нервової діяльності тощо [1]. Стрес є невід'ємним супутником нашого життя [2]. Він може призводити як до адаптації, так і до її зриву, розвитку різноманітних захворювань [3]. При надмірному стресі порушується робота внутрішніх органів, зокрема серцево-судинної системи [4]. Гіподинамія, брак часу для виконання роботи, безробіття призводять до розвитку дистресу. Визначення патогенетичних ланок, які б змогли розкрити механізми ушкоджувального впливу стресу, в особин з різною реактивністю сприятиме розробці індивідуальних методів корекції.

Мета дослідження - визначити вплив іммобілізаційного стресу на зміни пероксидного (с Ю. М. Ординський, О.В.Денефріль, 2018. окиснення ліпідів, антиоксидантного захисту та показники електрокардіограм (ЕКГ) у щурів різної статі з високою і низькою стійкістю до гіпоксії (ВГ та НГ).

МЕТОДИ ДОСЛІДЖЕННЯ. ДосліДИ виконано на 96 щурах лінії Вістар, високо- і низькостійких до гіпоксії, віком 5,5-6 місяців. Тварин поділено на дві групи - контрольну та дослідну (які зазнали іммобілізаційного стресу). В кожній з груп було по 12 самців і 12 самиць. Особин з різною стійкістю до гіпоксії виділяли із загальної когорти тварин за методикою В. Я. Березовського [5]. Стрес моделювали шляхом чотириразової одногодинної іммобілізації щурів спинкою донизу 3 інтервалом 24 год між окремими стресовими епізодами [6].

Усі експерименти проводили в першій половині дня в спеціально відведеному приміщенні 
при температурі $18-22{ }^{\circ} \mathrm{C}$, відносній вологості 40-60 \% і освітленості 250 лк. Досліди виконано з дотриманням норм Європейської конвенції про захист хребетних тварин, що використовуються для дослідних та інших наукових цілей (Страсбург, 1986), ухвали Першого національного конгресу з біоетики (Київ, 2001) і наказу МОЗ України від 23.09.2009 р. № 690.

Евтаназію щурів проводили шляхом тотального кровопускання із серця після попереднього тіопентал-натрієвого наркозу (60 мг $\cdot \mathrm{r}^{-1}$ маси тіла тварини внутрішньочеревно). Для подальшого експериментального дослідження в гомогенаті серця визначали концентрацію дієнових (ДК) і трієнових кон'югатів (ТК), шифрфових основ (ШО) [7], ТБК-активних продуктів [8], активність супероксиддисмутази (СОД) [9], каталази [10]. 3 метою визначення ступеня порушення фуннкціонального стану кардіоміоцитів за допомогою пристрою "Кардіолаб" (Харків, Україна) реєстрували електрокардіограми з комп'ютерним аналізом тривалості інтервалів, зубців та їх амплітуди.

Статистичну обробку цисррових даних виконано за допомогою програмного забезпечення Excel ("Microsoft", CШA) i STATISTICA 6.0 ("Statsoft", США). Достовірність різниці значень між незалежними кількісними величинами визначали при нормальному розподілі за критерієм Стьюдента, в інших випадках - непараметричними методами.

РЕЗУЛЬТАТИЙ ОБГОВОРЕННЯ. У КОНТРОЛЬних ВГ самців, порівняно з НГ, виявлено нижчу активність процесів пероксидного окиснення ліпідів (ПОЛ), про що свідчили достовірно менші на $6,78 \%(p<0,001)$ показники ТБК-активних продуктів (табл. 1). При іммобілізаційному стресі у ВГ тварин відмічено значне збільшення первинних і проміжних продуктів ПОЛ: ДК - на $13,57 \%(p<0,001)$, ТК - на 11,35\% $(p<0,001)$, ТБК-активних продуктів - у 4,7 раза $(p<0,001)$, ШО - на 76,7 \% ( $<<0,001)$. У НГ щурів значення ДК зросли на 33,46 \% (p<0,001), ТК - на 38,11 \% $(p<0,001)$, вміст ТБК-активних продуктів підвищився в 3,08 раза $(p<0,001)$, ШО - на $64,48 \%$ $(p<0,001)$. Менші значення показників ПОЛ виявлено у ВГ тварин порівняно з НГ: ДК - на $21,15 \%(p<0,001)$ і ТK - на 29,10 \% ( $<<0,001)$, більші - ТБК-активних продуктів - на 30,06 \% $(p<0,001)$, ШО - на 10,8 \% ( $<<0,001)$. Отримані дані вказують на розвиток окиснювального і карбонільного стресу у ВГ та НГ щурів-самців. У НГ тварин переважали накопичення первинних і вторинних продуктів ПОЛ, нижча концентрація ШО, що можна пов'язати з меншим антиоксидантним захистом, знешкодженням кінцевих продуктів. У ВГ щурів відмічено більше накопичення проміжних і кінцевих продуктів ПОЛ, що може свідчити про високу потужність антиоксидантної системи.

У контрольних ВГ самиць, порівняно з НГ, була більша активність первинних, проміжних і кінцевих продуктів ПОЛ (ДК - на 14,38 \%, p $<0,001$, ТК - на 15,24 \%, p<0,001, ШО - на $31,12 \%, p<0,001)$ і менша концентрація ТБК-активних продуктів (на 8,01 \%, p<0,001). Отримані дані можуть вказувати на інтенсивніший перебіг процесів ПОЛ у інтактних ВГ самиць, що може

Таблиця 1 - Зміни показників пероксидного окиснення ліпідів, викликані іммобілізаційним стресом, у високо- і низькостійких до гіпоксії тварин різної статі (Mm, n=12)

\begin{tabular}{|c|c|c|c|c|}
\hline \multirow[b]{2}{*}{ Група } & \multicolumn{4}{|c|}{ Показник } \\
\hline & $\begin{array}{c}\text { дієнові кон'югати, } \\
\text { ум. од. } \cdot \text { мг }^{-1}\end{array}$ & $\begin{array}{c}\text { трієнові кон'югати, } \\
\text { ум. од. } \text { мг }^{-1}\end{array}$ & $\begin{array}{c}\text { ТБК-активні продукти, } \\
\text { мкмоль/кг }\end{array}$ & $\begin{array}{c}\text { шиффрові основи, } \\
\text { ум. од. } \text { мг }^{-1}\end{array}$ \\
\hline \multicolumn{5}{|c|}{ Самці } \\
\hline \multicolumn{5}{|c|}{$\mathrm{B \Gamma}$} \\
\hline Контроль & $0,975 \pm 0,021$ & $0,994 \pm 0,013$ & $0,906 \pm 0,012$ & $1,413 \pm 0,100$ \\
\hline Стрес & $1,108 \pm 0,028^{*}$ & $1,107 \pm 0,028^{\star}$ & $4,255 \pm 0,024^{*}$ & $2,496 \pm 0,063^{*}$ \\
\hline \multicolumn{5}{|c|}{$\mathrm{H \Gamma}$} \\
\hline Контроль & $1,005 \pm 0,010$ & $1,035 \pm 0,019$ & $0,967 \pm 0,006^{* *}$ & $1,354 \pm 0,055$ \\
\hline Стрес & $1,342 \pm 0,064^{*, * \star}$ & $1,429 \pm 0,017^{*, * \star}$ & $2,976 \pm 0,061^{*, * *}$ & $2,227 \pm 0,019^{*, * \star}$ \\
\hline \multicolumn{5}{|c|}{ Самиці } \\
\hline \multicolumn{5}{|c|}{$\mathrm{B \Gamma}$} \\
\hline Контроль & $0,952 \pm 0,024$ & $1,140 \pm 0,032^{\#}$ & $0,899 \pm 0,002$ & $1,100 \pm 0,016^{\#}$ \\
\hline Стрес & $1,027 \pm 0,023^{*}, \#$ & $1,091 \pm 0,015$ & $3,916 \pm 0,047^{*}, \#$ & $2,357 \pm 0,068^{*}$ \\
\hline \multicolumn{5}{|c|}{$\mathrm{H \Gamma}$} \\
\hline Контроль & $0,861 \pm 0,006^{* \star, \#}$ & $0,966 \pm 0,017^{*, \#}$ & $0,971 \pm 0,005^{* *}$ & $0,932 \pm 0,016^{* \star, \#}$ \\
\hline Стрес & $1,110 \pm 0,054^{*}$,\# & $1,141 \pm 0,047^{*}$,\# & $3,900 \pm 0,008^{*, \#}$ & $2,264 \pm 0,062^{*}$ \\
\hline
\end{tabular}

Примітки. Тут і в таблицях 2, 3:

1. * - показники достовірні порівняно з контролем.

2. ** - показники достовірні порівняно з ВГ тваринами.

3. * - показники достовірні порівняно із самцями відповідної групи. 
бути пов'язано з недостатнім антиоксидантним захистом.

При стресі у ВГ самиць відмічено значні зміни продуктів ПОЛ: показники ДК зросли на 7,83 \% ( $<<0,05)$, ТБК-активних продуктів - у 4,36 раза $(p<0,001)$, ШО - в 2,14 раза $(p<0,001)$. У НГ самиць усі показники підвищились: ДК - на $28,93 \%$ ( $p<0,001)$, ТК - на 18,16\% ( $<<0,001)$, ТБК-активних продуктів - в 4,02 раза ( $<<0,001)$, а ШО - в 2,43 раза ( $<<0,001)$. Різниці показників продуктів ПОЛ у ВГ і НГ тварин при стресі не відзначено. Отримані дані свідчать про те, що у ВГ та НГ самиць, як і в самців, виникає окиснювальний і карбонільний стрес, більше виражений у НГ.

У контрольних ВГ самців, порівняно з ВГ самицями, виявлено менші на 14,67\% (p<0,001) показники ТК і більші на 22,12 \% (p<0,002) значення ШО. У НГ самців, порівняно з НГ самицями, були вищими на 14,38 \% ( $<<0,001)$ показники ДК, на 31,12 \% (p<0,001) - ШО, нижчими на $6,63 \%(p<0,02)$ - ТК. Дані результати в самиць, порівняно із самцями, вказують на інтенсивніший перебіг у останніх ПОЛ, менш потужну роботу антиоксидантної системи, що спричинює знешкодження продуктів ПОЛ, оскільки утворюється більше ШО. При стресі відмічено інтенсивніший перебіг ПОЛ у самців. У ВГ самців, порівняно з ВГ самицями, показники ДК були вищими на 7,3 \% ( $<<0,05)$, ТБК-активних продуктів - на 7,95 \% ( $<<0,001) ;$ у НГ самців, порівняно з НГ самицями, значення ДК були більшими на $17,28 \%$ ( $<<0,01)$, ТК - на 20,11\% ( $<<0,001)$, а ТБК-активних продуктів - меншими на 31,07 \% $(p<0,001)$. Отже, в самців стрес спричинює інтенсивніший перебіг ПОЛ, що може бути пов'язано з вищою активацією симпатичного відділу автономної нервової системи, меншою потужністю або більшими витратами антиоксидантів, відсутністю протекторного впливу статевих гормонів.

При вивченні фрерментативної ланки антиоксидантного захисту (табл. 2) виявлено, що в контролі у серці ВГ самців, порівняно з НГ, була вищою на 37,33 \% (p<0,001) активність СОД. Отримані результати вказують на менший вміст продуктів ПОЛ у ВГ самців порівняно з НГ.

При стресі у ВГ самців активність антиоксидантів не змінювалась, а в НГ активність СОД зростала на 89,42 \% (р<0,001), каталази - на $17,43 \%$ ( $<<0,001)$. У НГ тварин активність каталази виявилася меншою на 14,71 \% ( $<<0,001)$. Як свідчать отримані дані, нижча концентрація продуктів ПОЛ дійсно забезпечується вищою активністю антиоксидантного захисту організму у ВГ самців.

У контролі у ВГ самиць, порівняно з НГ, була вищою на 20,65 \% (р<0,001) активність СОД, нижчою в 3,07 раза \% (p<0,001) - активність каталази. Отримані результати вказують на інтенсивніший перебіг ПОЛ і антиоксидантного захисту у ВГ самиць, більша ж активність каталази у НГ тварин забезпечує менше накопичення продуктів ПОЛ.

При стресі у ВГ самиць активність СОД зростала у 2,25 раза ( $<<0,001)$, каталази - в 13,28 раза ( $<<0,001)$. У НГ самиць, відповідно, активність СОД збільшувалася в 3,7 раза ( $p<0,001)$, каталази - в 4,34 раза ( $<0,001)$. Така потужна активація антиоксидантного захисту сприяла меншому накопиченню продуктів ПОЛ і, можливо, незначному ураженню кардіоміоцитів.

В інтактних самців, порівняно із самицями, вища активність СОД (у ВГ - на 16,79\%, р<0,001, у НГ - на 9,32\%, р<0,001) і каталази (у ВГ - на $77,95 \%$, р<0,001, у НГ - на $13,72 \%$, p<0,01). Після перенесеного стресу при порівнянні результатів між самцями і самицями в самиць

Таблиця 2 - Зміни показників антиоксидантної системи, викликані стресом,

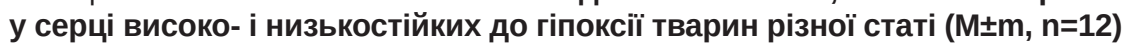

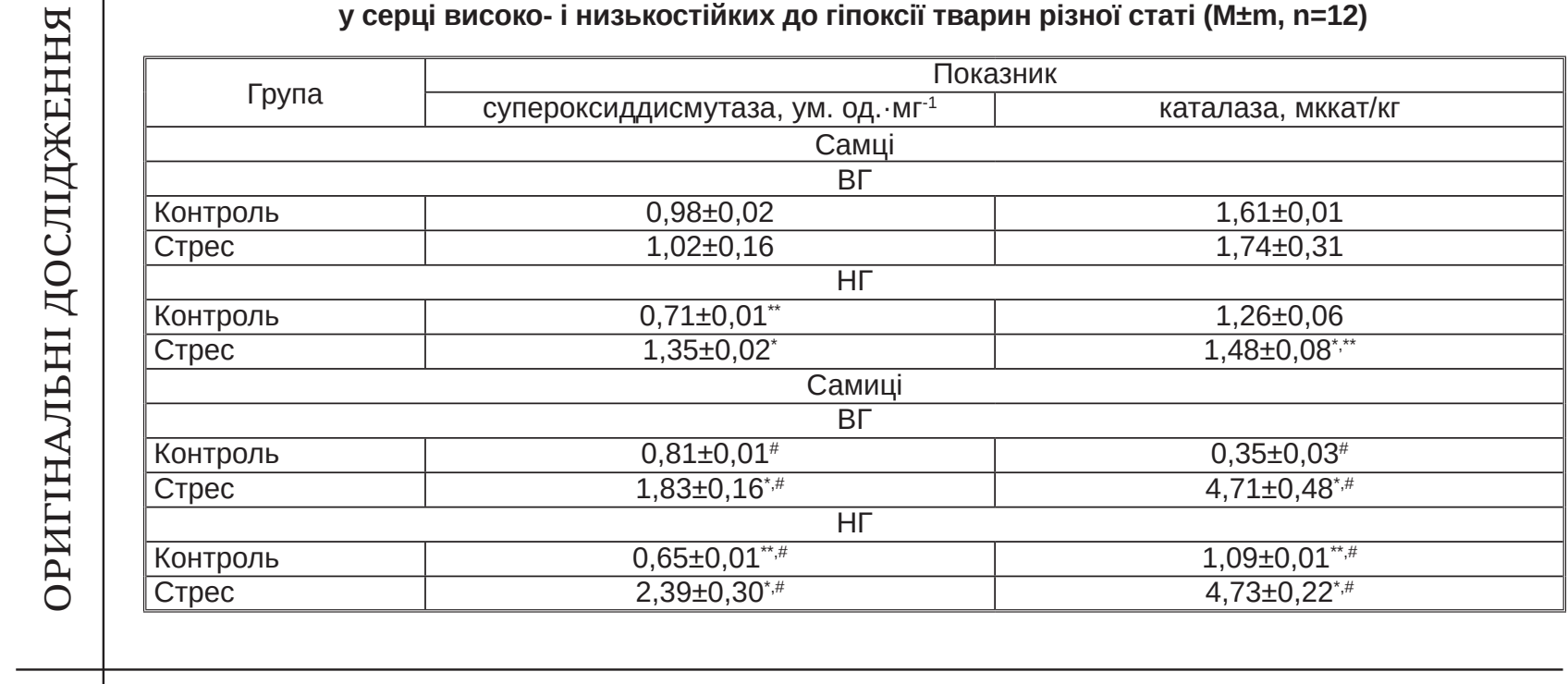


виявлено більшу активність СОД (у ВГ - на $79,10 \%, p<0,001$, у НГ - на 77,08 \%, p<0,001) i каталази (у ВГ - у 2,71 раза, $р<0,001$, у НГ - у $3,19$ раза, $p<0,001)$. Отримані дані вказують на те, що більша активація СОД і каталази у самиць забезпечує менше накопичення вторинних і кінцевих продуктів пероксидації ліпідів у серці.

У ВГ самців не відмічено компенсаторного зростання антиоксидантних фрерментів, що, можливо, пов'язано з вмістом вуглекислого газу. 3 одного боку, вуглекислота захищає СОД від інактивації, а 3 іншого - утворюється вільний карбонатний радикал, здатний спричинити окисні ушкодження клітини. Карбонатний радикал стабільний і легко дисрундує з місця утворення, призводячи до окисних ушкоджень клітини, він має здатність до димеризації, що може слугувати одним із шляхів його детоксикації [11].

Під час дослідження показників ЕКГ (табл. 3) не виявлено різниці між ВГ і НГ щурів у контролі та при стресі. При дослідженні показників ЕКГ у самиць різниці не відзначено. При стресі у ВГ тварин збільшились амплітуда зубця R (на $33,5 \%, p<0,05)$, відхилення ST відносно ізолінії (на 45,8 \%, p<0,01). У НГ щурів зросла частота серцевих скорочень (на 15,7 \%, р<0,01), зменшилася тривалість інтервалів RR (на 14,2 \%, p $<0,01)$ та QTc (на $7,2 \%, p<0,01)$.

У контролі у ВГ самців, порівняно із самицями, менші тривалість інтервалу QTс (на 3,7 \%, $\mathrm{p}<0,05)$ та відхилення ST відносно ізолінії (на 54,3 \%, p<0,001). При стресі у ВГ самців, порів- няно із самицями, менша амплітуда зубця $\mathrm{R}$ (на $28,4 \%, p<0,01)$. У НГ самців і самиць показники ЕКГ достовірно не відрізнялися.

Отже, в самців не відмічено достовірних змін на ЕКГ при стресі. У ВГ самиць збільшилась амплітуда зубця R, сегмент ST піднявся над ізолінією. У НГ самиць зросла частота серцевих скорочень, зменшилася тривалість інтервалу QTC. У ВГ самців, порівняно із самицями, в контролі менша тривалість інтервалу QTc, сегмент ST перебував над ізолінією; після стресу в перших менша амплітуда зубця R.

ВИСНОВКИ. 1. У серці інтактних ВГ щурів-самців, порівняно з НГ тваринами такого ж віку, спостерігають меншу активність процесів пероксидного окиснення ліпідів за рахунок ТБК-активних продуктів; у ВГ самиць - більшу за рахунок дієнових і трієнових кон'югатів та шифрфових основ, у НГ-самиць - за рахунок ТБК-активних продуктів.

2. Іммобілізаційний стрес призводить до розвитку окиснювального та карбонільного стресу в щурів: у ВГ самців - за рахунок ТБК-активних продуктів і ШО, НГ самців - ДК, ТК, ВГ самиць - ТБК-активних продуктів і ШО, НГ самиць - ДК, ТК, ТБК-активних продуктів і ШО. Інтенсивніший перебіг процесів ПОЛ при хронічному стресі спостерігають у самців порівняно із самицями.

3. При стресі в серці відмічено активацію антиоксидантної системи захисту, що більше

Таблиця 3 - Зміни на електрокардіограмах, викликані стресом, у високо- і низькостійких до гіпоксії тварин різної статі (M $\pm \mathrm{m})$

\begin{tabular}{|c|c|c|c|c|}
\hline \multirow{2}{*}{ Показник } & \multicolumn{4}{|c|}{ Група } \\
\hline & \multicolumn{2}{|c|}{ контроль } & \multicolumn{2}{|c|}{ стрес } \\
\hline \multicolumn{5}{|c|}{ Самці } \\
\hline & $\mathrm{B} \Gamma(\mathrm{n}=12)$ & НГ $(n=12)$ & $\mathrm{B} \Gamma(n=10)$ & НГ $(n=12)$ \\
\hline पCC, $x^{-1}$ & $453,92 \pm 10,98$ & $424,25 \pm 10,83$ & $438,89 \pm 8,93$ & $458,75 \pm 12,89$ \\
\hline $\mathrm{RR}, \mathrm{MC}$ & $133,00 \pm 3,47$ & $142,25 \pm 3,47$ & $137,33 \pm 2,86$ & $131,83 \pm 3,59$ \\
\hline $\mathrm{P}, \mathrm{MC}$ & $11,67 \pm 1,00$ & $12,00 \pm 1,39$ & $13,33 \pm 1,51$ & $12,00 \pm 2,89$ \\
\hline$P, M B$ & $0,116 \pm 0,025$ & $0,110 \pm 0,017$ & $0,119 \pm 0,010$ & $0,057 \pm 0,028$ \\
\hline $\mathrm{PQ}, \mathrm{MC}$ & $39,33 \pm 3,58$ & $43,75 \pm 2,42$ & $36,00 \pm 3,22$ & $38,67 \pm 2,95$ \\
\hline $\mathrm{R}, \mathrm{MB}$ & $0,614 \pm 0,065$ & $0,705 \pm 0,051$ & $0,588 \pm 0,050$ & $0,586 \pm 0,074$ \\
\hline QT, MC & $76,00 \pm 4,52$ & $74,00 \pm 4,66$ & $86,00 \pm 3,93$ & $74,42 \pm 3,97$ \\
\hline QTC, Mc & $145,83 \pm 1,86$ & $151,00 \pm 1,82$ & $148,11 \pm 1,56$ & $145,33 \pm 1,98$ \\
\hline $\mathrm{ST}, \mathrm{MB}$ & $0,088 \pm 0,018$ & $0,075 \pm 0,039$ & $0,030 \pm 0,016$ & $0,113 \pm 0,042$ \\
\hline \multicolumn{5}{|c|}{ Самиці } \\
\hline & ВГ $(n=10)$ & НГ $(n=11)$ & $\mathrm{B \Gamma}(\mathrm{n}=12)$ & НГ $(n=12)$ \\
\hline पCC, $X^{-1}$ & $421,00 \pm 6,06$ & $394,36 \pm 15,73$ & $416,18 \pm 17,17$ & $456,30 \pm 12,56$ \\
\hline $\mathrm{RR}, \mathrm{MC}$ & $142,80 \pm 2,00$ & $154,36 \pm 6,64$ & $146,36 \pm 5,86$ & $132,40 \pm 3,81^{*}$ \\
\hline $\mathrm{P}, \mathrm{MC}$ & $14,80 \pm 2,27$ & $14,73 \pm 1,17$ & $9,64 \pm 1,01$ & $11,20 \pm 0,95$ \\
\hline $\mathrm{P}, \mathrm{MB}$ & $0,104 \pm 0,022$ & $0,149 \pm 0,022$ & $0,091 \pm 0,012$ & $0,100 \pm 0,010$ \\
\hline $\mathrm{PQ}, \mathrm{MC}$ & $42,80 \pm 2,17$ & $47,45 \pm 3,35$ & $44,18 \pm 2,61$ & $39,40 \pm 2,81$ \\
\hline $\mathrm{R}, \mathrm{MB}$ & $0,565 \pm 0,086$ & $0,635 \pm 0,073$ & $0,754 \pm 0,028^{*, \#}$ & $0,730 \pm 0,113$ \\
\hline QT, MC & $85,20 \pm 3,74$ & $90,00 \pm 5,71$ & $84,45 \pm 2,60$ & $80,40 \pm 2,77$ \\
\hline QTC, Mc & $151,30 \pm 1,06^{\#}$ & $156,82 \pm 3,30$ & $152,91 \pm 3,04$ & $145,50 \pm 2,04^{*}$ \\
\hline ST, MB & $-0,048 \pm 0,036^{\#}$ & $-0,015 \pm 0,039$ & $0,070 \pm 0,015^{*}$ & $0,039 \pm 0,017$ \\
\hline
\end{tabular}


виражено в самиць порівняно із самцями. У ВГ самців активації СОД і каталази не відзначено.

4. При іммобілізаційному стресі порушуються процеси автоматизму, збудливості та провідності тільки в самиць.

\section{СПИСОК ЛІТЕРАТУРИ}

1. Crea F. Sex differences in mechanisms, presentation and management of ischaemic heart disease / F. Crea, I. Battipaglia, F. Andreotti // Atherosclerosis. 2015. - 241 (1). - P. 157-168.

2. Kötter T. Resource-oriented coaching for reduction of examination-related stress in medical students: an exploratory randomized controlled trial / T. Kötter, F. Niebuhr // Adv. Med. Educ. Pract. - 2016. - 7. P. 497-504.

3. Expressive flexibility in combat veterans with posttraumatic stress disorder and depression / R. Rodin, G. A. Bonanno, N. Rahman [et al.] // J. Affect. Disord. 2016. - 207. - P. 236-241.

4. Angina and mental stress-induced myocardial ischemia / P. Pimple, A. J. Shah, C. Rooks [et al.] // J. Psychosom. Res. - 2015. - 78 (5). - P. 433-437.

5. Березовский В. А. Гипоксия и индивидуальные особенности реактивности / В. А. Березовский. - К. : Наукова думка, 1978. - 216 с.

6. Кулинский В. И. Две адаптационные стратегии в неблагоприятных условиях: резистентная и толе-

\section{REFERENCES}

1. Crea, F., Battipaglia, I., \& Andreotti F. (2015). Sex differences in mechanisms, presentation and management of ischaemic heart disease. Atherosclerosis, 241 (1), 157-168

2. Kötter, T., \& Niebuhr, F. (2016). Resource-oriented coaching for reduction of examination-related stress in medical students: an exploratory randomized controlled trial. Adv. Med. Educ. Pract., 7, 497-504.

3. Rodin, R., Bonanno, G.A., Rahman, N., Kouri, N.A., Bryant, R.A., Marmar, C.R., \& Brown, A.D. (2016). Expressive flexibility in combat veterans with posttraumatic stress disorder and depression. J. Affect. Disord., 207, 236-241.

4. Pimple, P., Shah, A.J., Rooks, C., Bremner, J.D., Nye, J., Ibeanu, I., Raggi P., and Vaccarino, V. (2015). Angina and mental stress-induced myocardial ischemia. J. Psychosom. Res., 78 (5), 433-437.

5. Berezovskyy, V.A. (1978). Gipoksiya i individualnye osobennosti reaktivnosti [Hypoxia and individual particularities of reactivity]. Kyiv: Naukova dumka [in Russian].

6. Kulinskiy, V.I., \& Olkhovskiy, I.A. (1992). Dve adaptatsionnye strategii $v$ neblagopriyatnikh usloviyakh: re-
Перспективи подальших досліджень. Для вияснення механізмів кардіопротекторної дії буде проведено аналіз вегетативного забезпечення серцевого ритму та морфологічне дослідження серця і надниркових залоз.

рантная. Роль гормонов и рецепторов / В. И. Кулинский, И. А. Ольховский // Успехи современной биологии. - 1992. - 112. - С. 697-711.

7. Хышиктуев Б. С. Методы определения продуктов перекисного окисления липидов в конденсате выдыхаемого воздуха и их клиническое значение / Б. С. Хышиктуев, Н. А. Хышиктуева, В. Н. Иванов // Клинич. лаб. диагностика. - 1996. - № 3. - С. 13-15.

8. Доклінічні дослідження лікарських засобів : метод. рек. / за ред. О. В. Стефранова. - К. : Авіцена, 2001. -528 c.

9. Чевари С. Роль супероксиддисмутазы в окислительных процессах клетки и метод определения ее в биологических материалах / С. Чевари, И. Чаба, Й. Секей // Лаб. дело. - 1985. - № 11. - С. 678-681.

10. Метод определения активности каталазы / М. А. Королюк, Л. И. Иванова, И. Г. Майорова, В. Е. Токарев // Лаб. дело. - 1988. - № 1. - С. 16-19.

11. Морозова В. С. Функціонування антиоксидантної системи міокарду щурів за умов штучного гіпобіозу / В. С. Морозова // Вісн. проблем біології і медицини. - 2013. - 2 (103), вип. 3. - С. 86-90.

zistentnaya i tolerantnaya. Rol gormonov i retseptorov [Two adaptation strategies in adverse conditions: resistant and tolerant. The role of hormones and receptors]. Uspekhi sovremennoy biologii-Advances of Modern Biology, 112, 697-711 [in Russian].

7. Khyshiktuyev, B.S., Khyshiktuyeva, N.A., \& Ivanov, V.N. (1996). Metody opredeleniya produktov perekisnogo okisleniya lipidov $v$ kondensate vydykhayemogo vozdukha i ikh klinicheskoe znachenie [Methods of determination of products of lipids peroxidation in exhaled air condensate and their clinical significance]. Klinicheskaya laboratornaya diagnostika - Clinical Laboratory Diagnostics, 3, 13-15 [in Russian].

8. Stefanov, O.V. (Ed.). (2001). Doklinichni doslidzhennia likarskykh zasobiv: metodychni rekomendatsii [Preclinical research of medicinal products: methodical recommendations]. Kyiv: Avitsenna [in Ukrainian].

9. Chevary, S., Chaba, I., \& Sokei, Y. (1985). Rol superoksiddysmutazy $v$ okislitelnykh protsessakh kletki i metod opredeleniya ee $v$ biologicheskikh materialakh [The role of superoxide dismutase in the oxidative processes of the cell and the method for its determination 
in biological materials]. Laboratornoye delo - Laboratory Work, 11, 678-681 [in Russian].

10. Korolyuk, M.A., Ivanova. L.I., Mayorova, I.G., \& Tokarev, V.E. (1988). Metod opredeleniya aktivnosti katalazy [Method for determination of catalase activity]. Laboratornoye delo - Laboratory Work, 1, 16-19 [in Russian].
11. Morozova, V.S. (2013). Funktsionuvannia antyoksydantnoi systemy miokardu shchuriv za umov shtuchnoho hipobiozu [Functioning of the antioxidant system of myocardium of rats under conditions of artificial gipobiosis]. Visnyk problem biolohii i medytsyny - Bulletin of Biological and Medical Problems, 2 (103), 3, 86-90 [in Ukrainian].

Ю. М. Ордынский, О. В. Денефиль ТЕРНОПОЛЬСКИЙ ГОСУДАРСТВЕННЫЙ МЕДИЦИНСКИЙ УНИВЕРСИТЕТ ИМЕНИ И. Я. ГОРБАЧЕВСКОГО

\section{ИЗМЕНЕНИЯ БИОХИМИЧЕСКИХ ПОКАЗАТЕЛЕЙ И ФУНКЦИОНАЛЬНОЙ АКТИВНОСТИ СЕРДЦА ВЫСОКО- И НИЗКОУСТОЙЧИВЫХ К ОСТРОЙ ГИПОКСИЧЕСКОЙ ГИПОКСИИ КРЫС РАЗНОГО ПОЛА ПРИ ИММОБИЛИЗАЦИОННОМ СТРЕССЕ}

\section{Резюме}

Вступление. Определение механизмов повреждающего воздействия стресса на сердце у особей с различной реактивностью может способствовать разработке индивидуальных методов коррекции.

Цель исследования - определить влияние иммобилизационного стресса на изменения перекисного окисления липидов, антиоксидантной защиты и показатели электрокардиограмм у крыс разного пола с высокой и низкой устойчивостью к гипоксии (ВГ и НГ).

Методы исследования. Стресс моделировали 4 раза путем одночасовой иммобилизации крыс спинкой вниз с интервалом 24 часа. В сердце определяли концентрацию диеновых и триеновых конъюгатов, иифрфовых оснований, ТБК-активных продуктов, активность супероксиддисмутазы, каталазы. Регистрировали электрокардиограммы.

Результаты и обсуждение. У контрольных ВГ самцов, по сравнению с НГ, выявлено более низкую активность процессов перекисного окисления липидов, более высокую активность супероксиддисмутазы, в ВГ самок по сравнению с НГ - больше продуктов перекисного окисления липидов, супероксиддисмутазы, более низкую активность каталазы. Иммобилизация привела к развитию окислительного и карбонильного стресса, больше у самцов по сравнению с самками. При исследовании электрокардиограмм только в условиях стресса у ВГ самок увеличились амплитуда зубца $R$, отклонения ST относительно изолинии, в НГ возрасла частота сердечных сокращений, уменьшилась продолжительность интервалов RR u QTc.

Выводы. Интервальная иммобилизация крыс приводит к окислительному и карбонильному стрессу в сердце, но механизмы его развития зависят от устойчивости к гипоксии и пола. При иммобилизационном стрессе изменения на электрокардиограммах отмечено только у самок.

КЛЮЧЕВЫЕ СЛОВА: стресс; крысы; резистентность к гипоксии; перекисное окисление липидов; антиоксидантная система; электрокардиограммы.

\section{CHANGES OF BIOCHEMICAL INDEXES AND FUNCTIONAL ACTIVITY OF HEART OF HIGH AND LOW-RESISTANCE TO ACUTE HYPOXIC HYPOXIA IN RATS OF DIFFERENT SEX IN IMMOBILIZATIONAL STRESS}

\section{Summary}

Introduction. Determining the mechanisms of damaging the influence of stress on the heart in persons with different reactivity can contribute to the development of individual methods of correction. 
The aim of the study - to determine the effect of immobilization stress on changes in peroxide lipid oxidation, antioxidant defense and ECG indices in rats of different sex with high and low resistance to hypoxia (HR, LR).

Research Methods. Stress was modeled 4 times by an hour immobilization of rats on a back down with an interval of 24 hours. In the heart, the diene and triaene conjugates, schiff bases, TBA-active products, superoxide dismutase (SOD), catalase activity were determined. ECG was recorded.

Results and Discussion. In control HR males, in comparison with LR, lower activity of lipid peroxidation (LPO), higher activity of SOD was observed; in HR-females, in comparison with $L R$, more products of $L P H, S O D$, lesS activity of catalase. Immobilization led to oxidative and carbonyl stress, more in males, compared to females. In the study of ECG only when stressed in HR-females increased the amplitude of the wave $R$, the deviation of ST relative to the isoline; In LR, the heart rate increased, the duration of the interval RR and QTC decreased.

Conclusions. Interval immobilization of rats leads to oxidative and carbonyl stress in the heart, but the mechanisms of their development depend on resistance to hypoxia and sex. With immobilization stress, changes in ECG are noted only in females.

KEY WORDS: stress; rats; resistance to hypoxia; lipid peroxidation; antioxidant system; ECG.

Отримано 13.07.18

Адреса для листування: О. В. Денефріль, Тернопільський державний медичний університет імені І. Я. Горбачевського, майдан Волі, 1, Тернопіль, 46001, Україна, e-mail: denefil@tdmu.edu.uа. 